\title{
PENERAPAN THEORY OF CONSTRAINTS SEBAGAI UPAYA UNTUK MENGOPTIMALKAN KAPASITAS PRODUKSI KOTAK DI PT. ABC
}

\author{
Andres, Lamto Widodo, dan Reynold \\ Program Studi Teknik Industri Universitas Tarumanagara \\ e-mail: andrestjhia@gmail.com
}

\begin{abstract}
ABSTRAK
PT. ABC adalah perusahaan milik swasta yang mengkhususkan diri pada plastic cutting, vacum forming, packaging (plastik dan kotak). PT. ABC memiliki masalah dengan jumlah kapasitas produksi pada produksi kotak. Ini menyebabkan pabrik tidak dapat memenuhi permintaan pelanggan. Tujuan dari makalah ini adalah untuk mengoptimalkan kapasitas produksi kotak dengan menerapkan lima prinsip perbaikan berkelanjutan Theory of Constraints (TOC). Alat pengukuran yang digunakan pada penelitian adalah dengan menggunakan stopwatch. Etode yang digunakan dalam penelitian ini adalah metode Theory of Constraint. Dari hasil penelitian didapatkan bahwa kekurangan kapasitas terjadi pada stasiun kerja pattern printing sebesar 4,2 jam. Pada penelitian ini diberikan dua alternative usulan, yaitu overtime dan penambahan mesin pada stasiun kerja yang merupakan penyebab terjadinya penumpukan/bottleneck. Setelah menganalisis biaya dan keuntungan setiap alternatif, didapatkan bahwa alternatif overtime memperoleh keuntungan paling besar. Keuntungan yang diperoleh per-bulan sebesar Rp. 118.078.070.
\end{abstract}

Kata kunci: Kemacetan, Stasiun Kerja, Theory of Constraints, Optimasi Kapasitas

\begin{abstract}
PT. ABC is a private company that specializing in plastic cutting, vacuum forming, packaging (plastic and boxes). PT. ABC has a problem with the amount of production capacity on the production box. This causes the factory can't fulfill customer demand. The purpose of this paper is to optimizing the box production capacity with applying five principles of continuous improvement Theory of Constraints (TOC). Measurement tools used in the research is stopwatch. The method used in this research is the Theory of Constraint.The result showed that the lack of capacity occurs at pattern printing work station is 4,2 hours. The Author gives two alternatives which is ads time working hours/overtime and additional machines to the work station which is the causes of bottleneck. After analyzing the cost and benefits of each alternative, it was found that the addition of overtime gain the most benefit. Profits earned each month are Rp. 118.078.070.
\end{abstract}

Keywords: Bottleneck, Work Stations, Theory of Constraints, Optimizing Capacity.

\section{PENDAHULUAN}

Dalam lingkungan perusahaan bertipe manufaktur dengan produksi massal, peranan pengaturan sebuah lini produksi sangatlah penting, terutama dalam efisiensi lini produksi. PT. ABC memiliki masalah dengan jumlah kapasitas produksi pada lini produksi kotak. Ini menyebabkan pabrik tidak dapat memenuhi permintaan konsumen. Perusahaan membagi pekerjaan kepada pabrik percetakan lainnya dengan syarat pembagian keuntungan untuk memenuhi kebutuhan konsumen. Pengaturan lini produksi yang tidak tepat mengakibatkan setiap stasiun kerja di lintasan produksi mempunyai kecepatan produksi yang berbeda. Akibatnya adalah terjadi penumpukan material diantara kerja yang tidak berimbang dengan kecepatan produksinya. Dengan mengoptimalkan kapasitas produksi, diharapkan dapat mengurangi bottleneck yang terjadi. 
Untuk memenuhi kebutuhan pelanggan yang besar dibutuhkan perencanaan produksi yang baik. Kurang efektifnya lini produksi pada bagian kotak mengakibatkan terjadinya bottleneck pada stasiun kerja. Untuk mencapai efisiensi kerja, maka proses bottleneck harus diminimalkan. Tujuan dari penelitian ini adalah mengoptimalkan kapasitas produksi dengan melakukan pendekatan Theory of Constraints. Dengan mengoptimalkan kapasitas produksi maka bottleneck dapat diminimumkan dan perusahaan dapat memenuhi permintaan konsumen.

Keuntungan berasal dari semua transaksi atau kejadian yang terjadi pada badan usaha dan akan mempengaruhi kegiatan perusahaan pada periode tertentu dan laba di dapat dari selisih antara pendapatan dengan beban, apabila pendapatan lebih besar dari pada beban maka perusahaan akan mendapatkan keuntungan apabila terjadi sebaliknya maka perusahaan mendapatkan rugi.

Bottleneck merupakan suatu filosofi manajemen yang berdasarkan prinsip-prinsip pencapaian peningkatan terus menerus (Continuous Improvement) melalui pemfokusan perhatian pada kendala sistem (system constraint): identifikasi konstrain sistem (identifying the constraint), eksploitasi konstrain (exploiting the constraint), subordinasi sumber lainnya (subordinating the remaining resources), elevasi konstrain (Elevating the constraint) dan mengulangi proses keseluruhan (repeating the process).

Dengan metode Theory of Constraint ini bottleneck pun dapat diminimumkan dari constaint tersebut yang dimana dalam bottleneck, constraint dibagai menjadi dua yaitu Capacity-constraint resource dan Non capacity-constraint resource.

\section{METODE PENELITIAN}

Pengukuran waktu jam henti diaplikasikan untuk pekerjaan yang berlangsung singkat dan berulang-ulang (repetitive). Namun metode ini dapat pula diaplikasikan pada pekerjaan non-manufacture. Alat pengukuran yang digunakan pada penelitian adalah dengan menggunakan stopwatch.

Jika tingkat ketelitian 10\% dan tingkat keyakinan 95\% berarti bahwa pengukur membolehkan rata-rata hasil pengukurannya menyimpang sejauh $10 \%$ dari rata-rata sebenarnya dan kemungkinan berhasil mendapatkan hal ini adalah 95\%. Dengan kata lain jika pengukur sampai memperoleh rata-rata pengukuran yang menyimpang lebih dari $10 \%$ dari yang seharusnya, hal ini dibolehkan terjadi hanya dengan kemungkinan 5\%. Semakin tinggi tingkat ketelitian dan semakin besar tingkat keyakinan, maka semakin banyak pengukuran yang perlu dilakukan [1].

Beberapa cara menentukan faktor penyesuaian yaitu dengan cara Shumard, Westinghouse, dan objektif. Dalam penelitian ini akan digunakan cara Westinghouse. Cara Westinghouse mengarahkan penilaian pada 4 faktor yang dianggap menentukan kewajaran atau ketidakwajaran dalam bekerja, yaitu: keterampilan, usaha, kondisi kerja dan konsistensi [1].

Faktor kelonggaran merupakan hal-hal secara nyata yang dibutuhkan oleh pekerja. Faktor kelonggaran diberikan untuk tiga hal, yaitu: kelonggaran untuk kebutuhan pribadi, menghilangkan rasa fatigue dan hambatan tak terhindarkan.

Uji kenormalan data bertujuan untuk menentukan apakah data-data yang diperoleh telah berdistribusi normal atau tidak. Uji yang dipakai adalah uji kebaikan suai (Goodness of Fit Test). Uji ini digunakan untuk mengetahui apakah suatu populasi mengikuti suatu 
distribusi teoritis tertentu. Pengujian normalitas dengan uji Kolmogorov Smirnov menggunakan software IBM SPSS Statistic 20.

Syarat yang digunakan dalam uji Kolmogorov Smirnov yaitu sebagai berikut: jika nilai Kolmogorov Smirnov Z $>0,05$, maka data berdistribusi normal dan jika nilai Kolmogorov Smirnov $\mathrm{Z}<0,05$, maka data tidak berdistribusi normal

Uji keseragaman data bertujuan untuk mengetahui apakah hasil pengukuran waktu cukup seragam. Suatu data dikatakan seragam apabila data tersebut berada dalam rentang batas kontol. Batas kontrol yang digunakan yaitu batas kontrol atas (BKA) dan batas kontrol bawah (BKB). Langkah-langkah dalam melakukan uji keseragaman data yaitu sebagai berikut: Hitung rata-rata keseluruhan

$\bar{x}=\frac{\sum x}{n}$

Hitung standar deviasi

$\sigma=\sqrt{\frac{\sum(x-\bar{x})^{2}}{n-1}}$

Tentukan batas kontrol atas (BKA) dan batas kontrol bawah (BKB)

$\mathrm{BKA}=\bar{x}+3 . \sigma$

$\mathrm{BKB}=\bar{x}-3 . \sigma$

Cek nilai waktu siklus yang diperoleh dari pengukuran yang dilakukan apakah berada dalam batas kontrol. Jika ada nilai waktu siklus yang keluar dari batas kontrol, maka data tersebut akan dibuang. Kemudian, lakukan perhitungan kembali dari tahap 1 hingga kondisi dimana semua nilai waktu siklus berada di dalam batas kontol.

Uji kecukupan data dilakukan untuk mengetahui apakah data yang diambil sudah cukup atau belum untuk mewakili kondisi sebenarnya. Jumlah pengukuran yang diperlukan sangat berkaitan erat dengan tingkat ketelitian dan tingkat keyakinan yang dikehendaki.

$\mathrm{N}^{\prime}=\left[\frac{\mathrm{k} / \mathrm{s} \sqrt{\mathrm{N} \sum \mathrm{x}_{\mathrm{i}}{ }^{2}-\left(\sum \mathrm{x}_{\mathrm{i}}\right)^{2}}}{\sum \mathrm{x}_{\mathrm{i}}}\right]^{2}$

Jika $N^{\prime}<\mathrm{N}$, maka pengamatan yang dilakukan dianggap cukup. Sebaliknya jika N'>N, maka perlu dilakukan pengamatan lagi.

Pengukuran-pengukuran yang telah selesai menunjukkan bahwa data yang didapat mempunyai keseragaman yang dikehendaki dan jumlahnya telah memenuhi tingkat ketelitian dan keyakinan yang diinginkan. Oleh karena itu, data tersebut dapat diolah untuk memberikan waktu baku bagi setiap proses.

Waktu siklus adalah waktu penyelesaian satu satuan produk sejak bahan baku mulai diproses di tempat kerja yang bersangkutan.

$W s=\frac{\sum x}{n}$

Waktu normal untuk suatu elemen operasi kerja adalah semata-mata menunjukkan bahwa seorang operator yang berkualifikasi baik akan bekerja menyelesaikan pekerjaannya pada kecepatan/tempo kerja yang normal. Untuk menormalkan waktu kerja yang diperoleh dari pengukuran kerja akibat kecepatan kerja operator yang berbeda-beda maka pada dasarnya menggunakan penyesuaian [2].

Waktu normal $=$ Waktu siklus rata-rata * Performance Rating

Waktu baku atau waktu standar adalah waktu normal yang telah memperhitungkan faktor kelonggaran atau allowance tersebut.

Waktu baku $=$ Waktu normal* $(1+\mathrm{K})$ 
Ada beberapa langkah-langkah dalam pembuatan routing sheet, diantaranya [3]:

Menentukan jumlah produk per satuan waktu yang ingin dicapai dan jumlah jam kerja dalam satuan waktu tersebut. Tentukan pula waktu baku dan waktu setup mesin untuk setiap operasi.

Kapasitas Alat Teoritis/ hari $=\frac{\text { Jam Kerja per Hari-Waktu Setup Mesin per Hari }}{\text { Waktu Baku Proses }}$

Menghitung jumlah unit yang diharapkan dan jumlah unit yang disiapkan.

Melakukan perhitungan akan kapasitas dengan efisiensi. Efisiensi yang digunakan adalah efisiensi pabrik dari semua departemen.

Kapasitas dengan efisiensi $=\frac{\text { Jumlah unit yang disiapkan }}{\text { Efisiensi Pabrik }}$

Perhitungan jumlah mesin teoritis yang dibutuhkan untuk memenuhi kapasitas produksi tersebut.

Jumlah mesin teoritis $=\frac{\text { Produk dengan efisiensi }}{\text { Kapasitas mesin teoritis } x \text { Realibiltas Mesin }}$

Penyusutan Metode Garis Lurus ini adalah salah satu metode yang termasuk paling banyak diaplikasikan oleh perusahaan perusahaan di indonesia. Metode garis lurus ini menganggap aktiva tetap akan memberikan kontribusi yang merata di sepanjang masa penggunaannya, sehingga aset tetap akan mengalami tingkat penurunan fungsi yang sama dari periode ke periode hingga aset ditarik dari penggunaannya dalam operasional perusahaan [4].

$\mathrm{Dt}=\frac{P-S}{N}$

\section{METODOLOGI PENELITIAN}
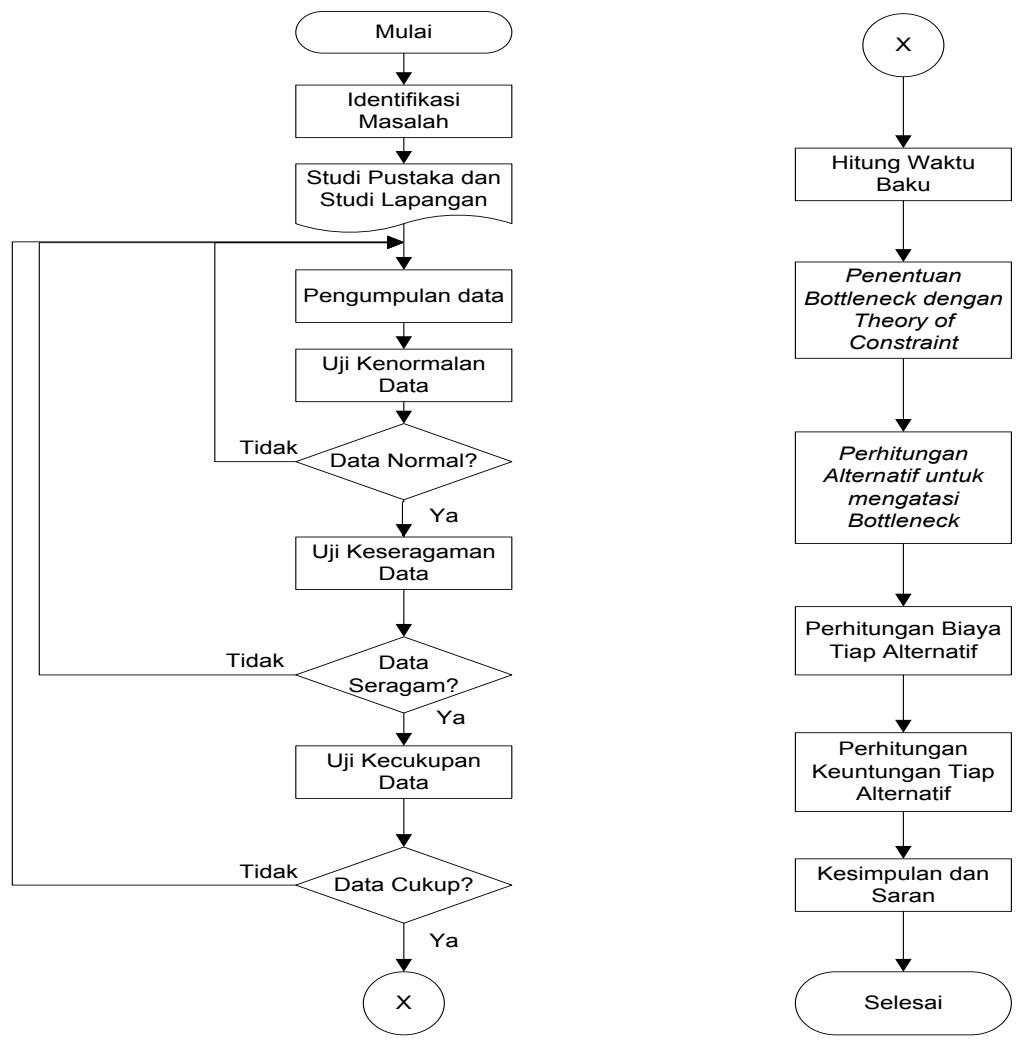

Gambar 1. Diagram Alir Penelitian 
Subjek penelitian atau responden adalah pihak-pihak yang dijadikan sebagai sampel dalam sebuah penelitian. Subjek penelitian juga membahas karakteristik subjek yang digunakan dalam penelitian, termasuk penjelasan mengenai populasi, sampel dan teknik sampling (acak/non-acak). Oleh karena itu, subjek yang akan diteliti yaitu PT. ABC yang berlokasi di Jl. Kamal Raya no.12 Blok DB, Tegal Alur, Jakarta Barat khususnya pada produksi kotak. PT. ABC bergerak dalam industri percetakan.

\section{Aliran Proses Produksi}

\section{HASIL DAN PEMBAHASAN}

Aliran proses produksi dapat dilihat pada Gambar 2.

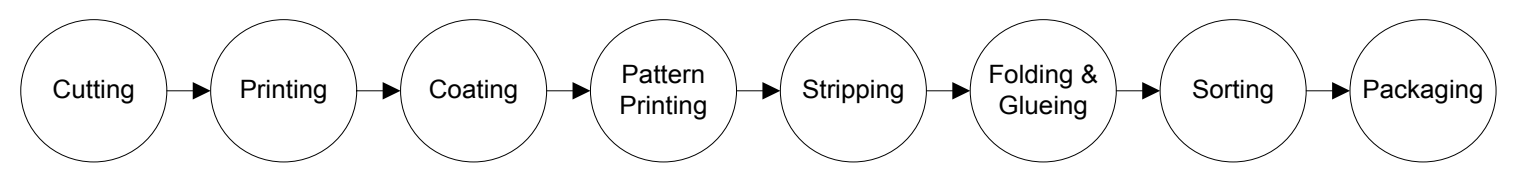

Gambar 2. Aliran Proses Produksi

Diagram Aliran dapat dilihat pada Gambar 3.

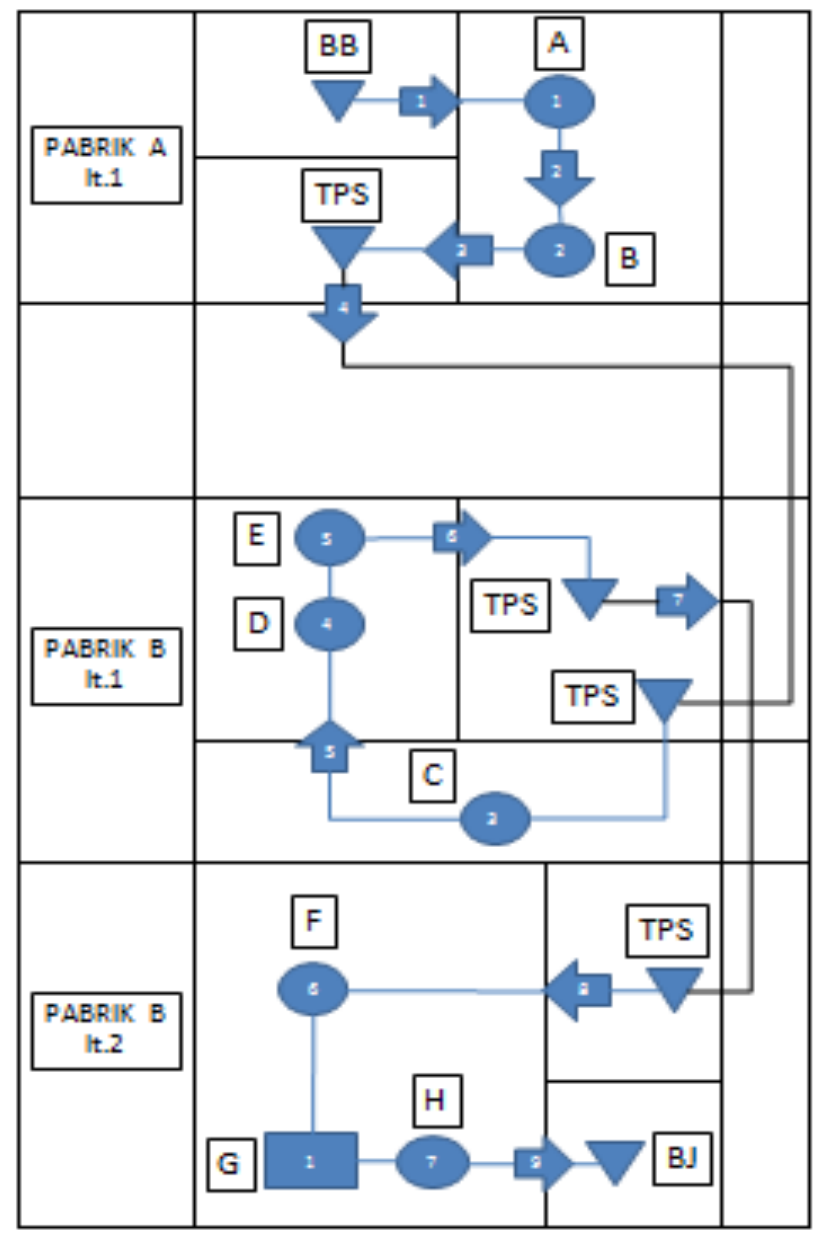

Gambar 3. Diagram Aliran 


\section{Pengukuran Waktu Kerja}

Pengukuran waktu kerja yang dilakukan yaitu dengan mengamati proses kerja operator perelemen kerjanya. Untuk proses Cutting/ Pemotongan, Printing, Coating, Pattern Printing, Stripping/ Pengupasan, Folding \& Glueing, Sorting/Sortir, pengamatan yang dilakukan sebanyak 30 sampel.

\section{Perhitungan Waktu Baku}

Setelah melakukan uji kecukupan data dan uji keseragaman data, maka selanjutnnya adalah menghitung waktu baku. Perhitungan waktu baku dapat dilihat pada Tabel 1.

Tabel 1. Perhitungan Waktu Baku

\begin{tabular}{lccccc}
\hline Stasiun Kerja & $\begin{array}{c}\text { Allowance } \\
(\%)\end{array}$ & $\begin{array}{c}\text { Waktu Normal } \\
\text { (detik) }\end{array}$ & $\begin{array}{c}\text { Waktu } \\
\text { Baku/Batch } \\
\text { (detik) }\end{array}$ & Batch & $\begin{array}{c}\text { Waktu Baku } \\
\text { (detik) }\end{array}$ \\
\hline Cutting & 16 & 3144,40 & 3718,26 & 9600 & 0,39 \\
Printing & 12 & 2457,54 & 2807,74 & 4800 & 0,58 \\
Coating & 15 & 3433,41 & 4025,68 & 4800 & 0,84 \\
Pattern Printing & 35 & 5096,44 & 6994,87 & 4800 & 1,46 \\
Stripping & 26 & 540,77 & 693,54 & 4800 & 0,14 \\
Folding\&Glueing & 15 & 2346,91 & 2751,75 & 4800 & 0,57 \\
Sorting & 21 & 474,72 & 585,09 & 4800 & 0,12 \\
Packaging & 14 & 2667,84 & 3101,36 & 4800 & 0,65 \\
\hline
\end{tabular}

\section{Penentuan Bottleneck}

Penentuan bottleneck akan dihitung pada setiap proses produksi. Sebelum melakukan penentuan bottleneck, terlebih dahulu harus diketahui berapa jumlah produk yang akan di produksi. Dalam penelitian ini produk yang diambil adalah produksi kotak. Persentase beban dapat dilihat pada Tabel 2.

Tabel 2. Penentuan Bottleneck

\begin{tabular}{cccccc}
\hline Proses & $\begin{array}{c}\text { Waktu } \\
\text { Baku } \\
\text { (detik) }\end{array}$ & $\begin{array}{c}\text { Kapasitas } \\
\text { yang } \\
\text { Dibutuhkan } \\
\text { (detik) }\end{array}$ & $\begin{array}{c}\text { Kapasitas } \\
\text { yang } \\
\text { Tersedia } \\
\text { (detik) }\end{array}$ & $\begin{array}{c}\text { Persentase } \\
\text { Beban (\%) }\end{array}$ & Keterangan \\
\hline Cutting & 0.39 & 11619.55 & 28800 & 40.35 & Non- Bottleneck \\
Printing & 0.58 & 17548.37 & 28800 & 60.93 & Non- Bottleneck \\
Coating & 0.84 & 25160.48 & 28800 & 87.36 & Non- Bottleneck \\
Patern Printing & $\mathbf{1 . 4 6}$ & $\mathbf{4 3 7 1 7 . 9 3}$ & $\mathbf{2 8 8 0 0}$ & $\mathbf{1 5 1 . 8 0}$ & Bottleneck \\
Stripping & 0.14 & 4334.62 & 28800 & 15.05 & Non- Bottleneck \\
Folding\&Glueing & 0.57 & 17198.42 & 28800 & 59.72 & Non- Bottleneck \\
Sorting & 0.12 & 3656.83 & 28800 & 12.70 & Non- Bottleneck \\
Packaging & 0.65 & 19383.53 & 28800 & 67.30 & Non-Bottleneck \\
\hline
\end{tabular}

\section{Bottleneck dan Capacitiy Constraint Resources}

Setelah mengetahui proses mana yang mengalami bottleneck, proses tersebut harus ditentukan kembali mana yang menjadi Bottleneck-Capacity constraint resource, BottleneckNon Capacity constraint resources, Non Bottleneck-Capacity constraint resource, Non Bottleneck-Non Capacity constraint resource. Tabel pengelompokkan proses bottleneck tersebut dapat dilihat pada Tabel 3. 
Tabel 3. Pengelompokkan Proses yang Bottleneck

\begin{tabular}{ccc}
\hline & Bottleneck & Non-Bottleneck \\
\hline Capacity constraint resources & & Coating \\
& & Cutting \\
Non-Capacity constraint resources & Printing \\
& & Stripping \\
& & Folding\&Glueing \\
& Sorting \\
& Packaging \\
\hline
\end{tabular}

\section{Perhitungan Overtime}

Overtime yang diberikan pada stasiun pattern printing yaitu sebesar 4,2 jam/hari. Total waktu proses pada stasiun kerja pattern printing yaitu selama 12,2 jam/hari.

\section{Perhitungan Routing Sheet}

Routing sheet digunakan untuk mengetahui jumlah permintaan yang dibutuhkan (scheduled demand) dan untuk mencari jumlah kebutuhan mesin. Oleh karena itu routing sheet ini terdiri dari persentase efisiensi pabrik, reliabilitas mesin, waktu baku (menit), jumlah scrap, expected demand, dan jumlah mesin. Tabel Perhitungan Routing Sheet dapat dilihat pada Tabel 4.

Tabel 4. Tabel Perhitungan Routing Sheet

\begin{tabular}{|c|c|c|c|c|c|c|c|c|c|c|}
\hline $\begin{array}{c}\text { Deskripsi } \\
\text { Operasi }\end{array}$ & $\begin{array}{l}\text { Waktu } \\
\text { set up } \\
\text { (dtk) }\end{array}$ & $\begin{array}{l}\text { Waktu } \\
\text { Proses } \\
(\mathrm{dtk})\end{array}$ & $\begin{array}{l}\text { Kapasitas } \\
\text { Mesin } \\
\text { (lbr/hari) }\end{array}$ & $\begin{array}{c}\text { Kapasitas } \\
\text { Mesin } \\
\text { Teoritis } \\
\text { (lbr/hari) }\end{array}$ & $\begin{array}{c}\text { Scrap } \\
(\%)\end{array}$ & $\begin{array}{c}\text { Jumlah yang } \\
\text { Diharapkan } \\
\text { (lbr/hari) }\end{array}$ & $\begin{array}{c}\text { Jumlah yang } \\
\text { Dipersiapkan } \\
\text { (lbr/hari) }\end{array}$ & $\begin{array}{c}\text { Produksi } \\
\text { pada } \\
\text { Tingkat } \\
\text { Efisiensi } \\
\text { (lbr/hari) }\end{array}$ & $\begin{array}{l}\text { Jumlah } \\
\text { Mesin } \\
\text { Teoritis } \\
\text { (unit) }\end{array}$ & $\begin{array}{l}\text { Jumlah } \\
\text { Mesin } \\
\text { Aktual } \\
\text { (unit) }\end{array}$ \\
\hline Cutting & 0 & 0,39 & 74357,42 & 74357,42 & 1 & 30609 & 30918,30 & 32979,53 & 0,522 & 1 \\
\hline Printing & 0 & 0,58 & 49235,34 & 49235,34 & 1 & 30303 & 30609,12 & 32649,73 & 0,780 & 1 \\
\hline Coating & 0 & 0,84 & 34339,57 & 34339,57 & 0 & 30303 & 30303,03 & 32323,23 & 1,107 & 1 \\
\hline $\begin{array}{l}\text { Patern } \\
\text { Printing } \\
\text { Folding }\end{array}$ & 0 & 4,37 & 6587,69 & 6587,69 & 1 & 30000 & 30303,03 & 32323,23 & 5,772 & 3 \\
\hline $\begin{array}{c}\& \\
\text { Glueing } \\
\end{array}$ & 0 & 0,57 & 50237,16 & 50237,16 & 0 & 30000 & 30000,00 & 32000,00 & 0,749 & 1 \\
\hline
\end{tabular}

Dari Tabel diatas dapat diketahui bahwa mesin yang perlu ditambah berjumlah 3 mesin.

\section{Perhitungan Biaya Upah Lembur pada Alternatif Overtime}

Perhitungan Biaya pada Alternatif Overtime disesuaikan dengan jumlah jam kerja yang harus ditambahkan pada stasiun yang bottleneck. Tabel Perhitungan biaya Total Overtime dapat dilihat pada Tabel 5.

Tabel 5. Tabel Biaya Total Overtime

\begin{tabular}{lcc}
\hline \multicolumn{1}{c}{ Jenis Biaya/bulan } & Jumlah \\
\hline Biaya Listrik Lembur Hari Kerja & $\mathrm{Rp}$ & 999.398 \\
Biaya Listrik Lembur Hari Libur & $\mathrm{Rp}$ & 399.759 \\
Upah Lembur Operator & $\mathrm{Rp}$ & 7.397 .687 \\
Upah Lembur Co-Operator & $\mathrm{Rp}$ & 2.283 .286 \\
\hline Total Biaya & $\mathrm{Rp}$ & 11.079 .130 \\
\hline
\end{tabular}




\section{Perhitungan Biaya pada Alternatif Penambahan Mesin}

Perhitungan biaya pada alternatif penambahan mesin disesuaikan dengan jumlah mesin yang harus ditambahkan pada stasiun yang bottleneck. Tabel Perhitungan Biaya Total Penambahan Mesin dapat dilihat pada Tabel 6.

Tabel 6. Tabel Biaya Total Penambahan Mesin

\begin{tabular}{lcc}
\hline \multicolumn{1}{c}{ Jenis Biaya/bulan } & Jumlah \\
\hline Biaya Depresiasi Mesin & $\mathrm{Rp}$ & 2.404 .998 \\
Biaya Listrik & $\mathrm{Rp}$ & 2.665 .062 \\
Gaji Operator & $\mathrm{Rp}$ & 8.100 .000 \\
Gaji Co-Operator & $\mathrm{Rp}$ & 2.500 .000 \\
\hline Total Biaya & $\mathrm{Rp}$ & 15.670 .060 \\
\hline
\end{tabular}

\section{Total Keuntungan}

Setelah mengetahui biaya setiap alternatif, maka diketahui berapa jumlah peningkatan kuantitas yang terjadi. Dari jumlah peningkatan kuantitas,, didapatkan selisih keuntungan pada setiap alternatif.

- Alternatif $1=$ Overtime

- Alternatif $2=$ Penambahan Mesin

Tabel 7 Tabel Perbandingan Total Keuntungan

\begin{tabular}{|c|c|c|c|c|c|}
\hline $\begin{array}{c}\text { Jenis } \\
\text { Alternatif }\end{array}$ & $\begin{array}{c}\text { Peningkatan } \\
\text { Kuantitas (lbr) }\end{array}$ & Profit/bulan & Biaya /bulan & $\begin{array}{c}\text { Total } \\
\text { Keuntungan/bulan }\end{array}$ & $\begin{array}{c}\text { Idle } \\
\text { Capacity }\end{array}$ \\
\hline Alt-1 & 10800 & $\mathrm{Rp} \mathrm{129.157.200}$ & $\mathrm{Rp} 11.079 .130$ & $\mathrm{Rp} \mathrm{118.078.070}$ & 0 \\
\hline Alt-2 & 10800 & $\mathrm{Rp} 129.157 .200$ & $\mathrm{Rp} 15.670 .060$ & $\mathrm{Rp} 113.487 .140$ & 4339 \\
\hline
\end{tabular}

Dari tabel diatas dapat disimpulkan bahwa alternatif yang dipilih adalah alternatif yang pertama yaitu overtime. Alternatif overtime memiliki total keuntungan terbesar jika dibandingkan dengan alternatif kedua yaitu alternatif penambahan mesin. Dengan total keuntungan sebesar Rp 118,078,070/ bulan , tanpa adanya idle capacity.

\section{KESIMPULAN}

Berdasarkan hasil analisis tersebut dapat disimpulkan sebagai berikut: diketahui bahwa stasiun ke-4 yaitu stasiun kerja pattern printing mengalami bottleneck. Faktor yang menyebabkan bottleneck adalah jumlah waktu produksi yang melebihi dari kapasitas yang diberikan sehingga mengakibatkan tidak tercapainya target produksi dan kerugian terhadap perusahaan. Dengan menggunakan pendekatan metode Theory of Constraint maka dapat diketahui bahwa terjadi kekurangan kapasitas waktu produksi pada stasiun kerja pattern printing dan menyebabkan persentase beban yang tinggi sebesar $151,80 \%$. Dengan mengitung besar dari kekurangan kapasitas waktu produksi, maka diketahui jumlah waktu produksi yang harus ditambahkan pada stasiun kerja pattern printing, yaitu sebesar 4,2 jam/hari atau 21 jam/minggu. Dengan mengetahui besar kekurangan kapasitas produksi, maka terdapat beberapa alternatif untuk mengatasi bottleneck tersebut. Setelah itu dilakukan perhitungan biaya terhadap setiap alternatif. Alternatif yang memperoleh jumlah keuntungan paling besar adalah alternatif ke-1 yaitu Overtime. Dengan perolehan keuntungan sebesar Rp118.078.070/bulan. 


\section{REFERENSI}

[1] Apple, James. 1990. Tata Letak Pabrik dan Pemindahan Bahan. Edisi ketiga. Bandung: ITB.

[2] Dettmer, H. William. 1997. Goldratt's Theory of Constraints: A System Approach to Continuous Improvement. Wisconsin: ASQC Quality Press.

[3] Halim, A. (2000). Akuntansi Keuangan daerah (ed.3). Jakarta: Salemba

[4] Sugiyono. 2010. Metode Penelitian Pendidikan. Bandung: Alfabeta.

[5] Sutalaksana, Iftikar Z., Ruhana A, dan Jann H. T. 2006. Teknik Perancangan Sistem Kerja, Bandung : Penerbit ITB.

[6] Wignjosoebroto, Sritomo. 2003. Ergonomi studi gerak dan waktu. Surabaya: Guna Widya. 